\title{
Spatio-temporal changes in microphytobenthos structure analysed by pigment composition in a macrotidal flat (Bourgneuf Bay, France)
}

\author{
Vona Méléder*, Laurent Barillé, Yves Rincé, Michèle Morançais, Philippe Rosa, \\ Pierre Gaudin
}

Laboratoire d'Écophysiologie Marine Intégrée, UPRES EA 26 63, BP 92 208, 44322 Nantes cedex 3, France

\begin{abstract}
The aim of this study was to contribute to a better understanding of turbid coastal ecosystems, focusing on spatio-temporal changes at the mesoscale in microphytobenthos structures in a macrotidal bay (Bourgneuf, France). This was based on pigment analysis by high-pressure liquid chromatography (HPLC), reinforced by microscopy observations, in relation to sediment characteristics. Microphytobenthos assemblages of this mudflat were $97 \%$ dominated by diatoms, confirmed by HPLC analysis, which showed biomarker pigments of this group: chlorophyll $C$, fucoxanthin, diadinoxanthin and diatoxanthin. The main assemblage is constituted of epipsammic species, like Plagiogrammopsis, Achnanthes and Cocconeis, characterising mixed sediments. However, this could be replaced by epipelic species, like Plagiotropis, Pleurosigma and Staurophora, during summer due to station silting. Microphytobenthic photosynthetic active biomass in the first $2 \mathrm{~mm}$ varied spatially and temporally from 12.2 to $186.9 \mathrm{mg} \mathrm{chl} \mathrm{a} \mathrm{m}^{-2}$. The predominance of a biomass spatial variability reflected spatial changes in sediment grain size and water content. Biomass in the first $2 \mathrm{~mm}$ represented from 28 to $68 \%$ of the total amount in the first $10 \mathrm{~mm}$. This indicated an accumulation of biomass in illuminated layers and a biomass decrease with depth associated with increasing values of the ratio of phaeopigments $a$ and fucoxanthin to chlorophyll $a$ (phaeo a/chl $a$ and fuco/chl $a$ ). Both could exceed 1.00 in deeper layers. Temporal changes in microphytobenthos structure at the mesoscale were mainly linked to hydrodynamism. This is stronger in winter and responsible for allochthonous pigment input (lutein and phaeophytin $b$ ) and sediment mixing, as grazing activity by macro- and meiofauna, forming chlorophyll a breakdown products, is responsible for an increase in fuco/chl $a$ and phaeo a/chl a values during spring/summer.
\end{abstract}

KEY WORDS: Microphytobenthos · Diatoms · Pigments · High-pressure liquid chromatography · HPLC · Granulometry

\section{INTRODUCTION}

In turbid coastal ecosystems characterised by large intertidal mudflats and a limited macrophytic and phytoplanktonic production, microphytobenthos (unicellular photosynthetic eukaryotes and cyanobacteria) growing in the upper millimetres of illuminated sediment is a significant contributor to primary production (MacIntyre et al. 1996, Underwood \& Kromkamp 1999) and an important food source for deposit feeders
(Austen et al. 1999, Pinckney et al. 2003). After its resuspension by turbulence and shear stresses generated by tidal currents or wind waves, it may represent up to $50 \%$ of the microalgae present in the water column (De Jonge \& Van Beusekom 1992) and thus also contribute to the diet of suspension feeders (Riera \& Richard 1996, Barillé et al. 1997). Moreover, microphytobenthos, in producing extracellular polymeric substances (EPS) and forming biofilms at the sediment surface at low tide, acts as an agent of biogenic stabili- 
sation and influences its own resuspension and the turbidity of the water column (Riethmüller et al. 2000, Paterson \& Hagerthey 2001).

Before assessing the contribution of microphytobenthos to the functioning of coastal ecosystems, it is necessary to acquire descriptive data about its structure, such as its biomass and taxonomic composition, in particular its spatial and temporal distribution in relation to environmental variables. Recent studies have provided significant ecological information based on microphytobenthic pigment analysis by high-pressure liquid chromatography (HPLC). This allows the estimation of both biomass, using chlorophyll a (chl a) concentration in sediment, and taxonomic composition, using accessory pigment composition (Cariou-Le Gall \& Blanchard 1995, Brotas \& Plante-Cuny 1998, Lucas \& Holligan 1999, Brotas \& Plante-Cuny 2003, Cartaxana et al. 2003). Furthermore, HPLC enables the identification and quantification of degraded or allochthonous pigments, with the possibility of tracing their origin: microphytobenthos (damaged or not), deposited phytoplankton or macroalgal detrital input (Lucas \& Holligan 1999, Cartaxana et al. 2003).

The aim of this study is to contribute to a better understanding of spatio-temporal changes in microphytobenthos structure in the macrotidal bay of Bourgneuf (France) in relation to sediment characteristics. This understanding is of economic importance because of the shellfish activity of this bay. Since 1980 this main economic local resource has suffered from a low growth rate and fluctuations in the fattening of culti- vated oysters (Barillé-Boyer et al. 1997). This seems to be due to the overloading of the carrying capacity of the ecosystem, as is the case in the southern bay of Marennes-Oléron (Héral 1993).

In this study, changes in microphytobenthos structure (pigment composition, taxonomic composition and biomass) are assessed on a monthly and mesoscale basis during 15 mo using HPLC, species diversity and granulometric analysis of surface sediment.

\section{MATERIALS AND METHODS}

Study site. Bourgneuf Bay $\left(47^{\circ} \mathrm{N}, 2^{\circ} \mathrm{W}\right)$, located south of the Loire river, is a macrotidal biotope with a maximum tidal amplitude of $6 \mathrm{~m}$ during spring tides. The total surface area is $340 \mathrm{~km}^{2}$, of which $100 \mathrm{~km}^{2}$ of intertidal area is mainly constituted by mudflats (Fig. 1a). This bay is characterised by high turbidity levels ranging from 4 to $415 \mathrm{mg} \mathrm{l}^{-1}$ as daily average values (Haure et al. 1996) and reaching a maximum of $1 \mathrm{~g} \mathrm{l}^{-1}$ during spring tides. Annual mean concentrations of suspended particulate matter are higher in the northern part of the bay (154 $\mathrm{mg} \mathrm{l}^{-1}$ ), characterised by a strong hydrodynamism, than in the southern part (34 $\mathrm{mg} \mathrm{l}^{-1}$ ) (Haure \& Baud 1995). Oyster beds cover an area of $10 \mathrm{~km}^{2}$, this bay ranking 6th in France in Pacific oyster production (8600 tons $\mathrm{yr}^{-1}$ in 2001) (Agreste 2003) despite low growth performances.

Sampling programme. To assess microphytobenthic structure at the mesoscale during $15 \mathrm{mo}$, sampling was

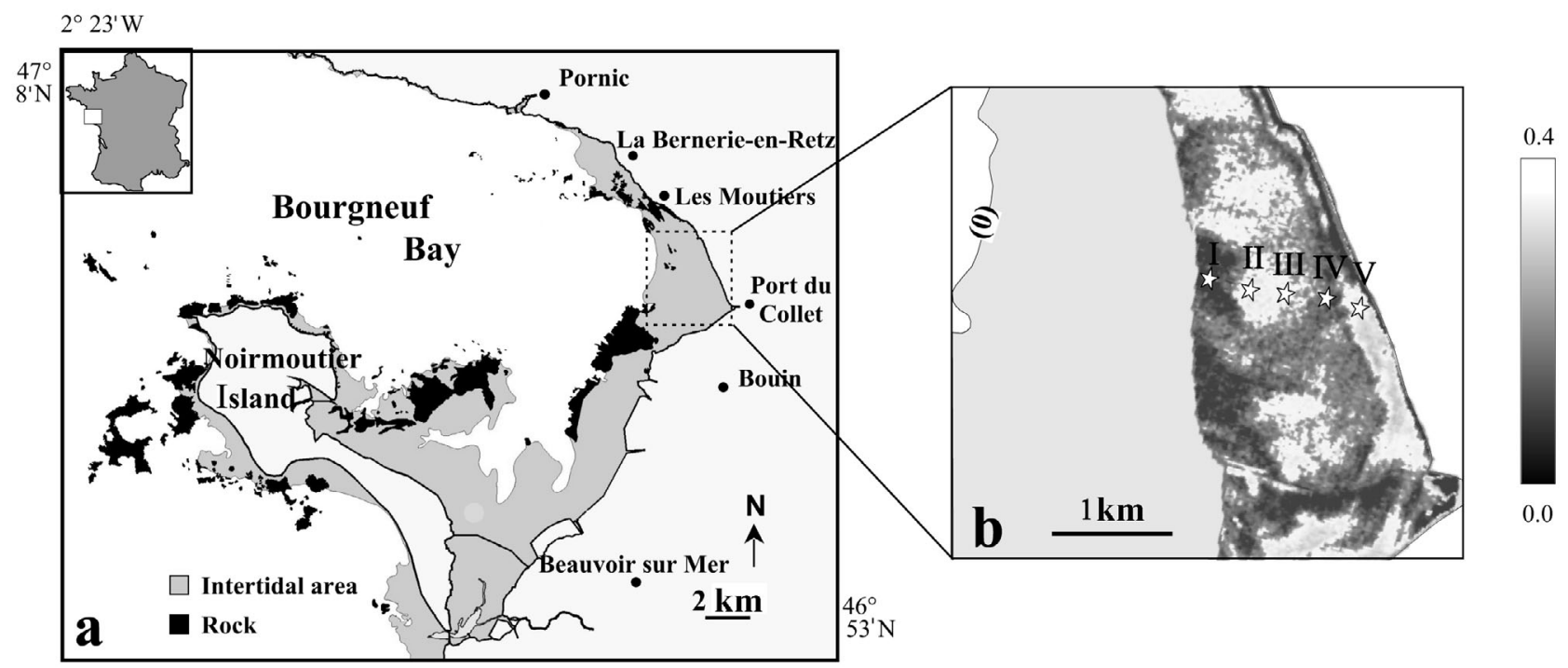

Fig. 1. Studied area. (a) Map of Bourgneuf Bay (France); (b) transect location from the intertidal flat. Stations are positioned on an extract of a calibrated SPOT image (delimited by the $+2 \mathrm{~m}$ isobath and the coastal line) through NDVI calculation (normalised difference vegetation index; grey scale), acquired in September 1998: low NDVI values (dark) correspond to low microphytobenthos coverage, whereas high NDVI values (clear) are associated with high microphytobenthos coverage 
distributed over stations and included a few sampling units per station, as recommended by Plante et al. (1986) and Saburova et al. (1995). Thus 5 stations from a transect were sampled monthly at low tide between May 2000 and July 2001 (Fig. 1b, Table 1). Stations were spaced at $300 \mathrm{~m}$, and sampling started at Stn I $\left(47^{\circ} 02.63^{\prime} \mathrm{N}, 2^{\circ} 00.72^{\prime} \mathrm{W}\right)$, the lowest altitudinal level, and finished at $\operatorname{Stn} \mathrm{V}\left(47^{\circ} 02.50^{\prime} \mathrm{N}, 1^{\circ} 59.54^{\prime} \mathrm{W}\right)$, the nearest to the beach and characterised by ridge and runnel features.

The location of the transect, in a storage and sedimentation zone (Lazure 1992), was chosen to be representative of the northern Bourgneuf Bay mudflat based on sedimentological, geomorphological and anthropic criteria (proximity of oyster beds). Moreover, recent studies (Méléder et al. 2003b, J.-Ph. Combe et al. unpubl.) of microphytobenthos mapping using visible-nearinfrared remote sensing suggest wide developments of microphytobenthos in the sampled region (Fig. 1b).

In each station, delimited by a $0.25 \mathrm{~m}^{2}$ quadrat, sediment cores (crystal polystyrene corer) of a $20 \mathrm{~cm}^{2}$ surface area were collected by hand on the basis of a systematic random sampling. This sampling unit was chosen to allow both sampling in microphytobenthos homogenous patches (ca. 60 to $100 \mathrm{~cm}^{2}$; Saburova et al. 1995) and in situ freezing by liquid nitrogen (sediment core diameter $5 \mathrm{~cm}$ ).

At the station scale, which was the microscale, specific assemblages remained similar in relation to the granulometric character of the sediment (Plante et al. 1986, Saburova et al. 1995). Thus, only 1 sediment core was collected for granulometry analysis and water content while a second core was used to analyse species diversity. On the other hand, sediment pigment content could vary at the microscale (Guarini et al. 1998). To estimate the average values of pigment content and

Table 1. Sampling dates on Bourgneuf Bay mudflat. Low tide time (in universal time, UT) and sampled stations are reported

\begin{tabular}{|ccl|}
\hline Sample date & Low tide (UT) & Sampled stations \\
\hline 5 May 2000 & $10: 40 \mathrm{~h}$ & II, III, IV \\
5 Jun 2000 & $11: 56 \mathrm{~h}$ & I, II, III, IV \\
3 Jul 2000 & $10: 53 \mathrm{~h}$ & I, II, III \\
31 Aug 2000 & $11: 09 \mathrm{~h}$ & I, II, III, IV, V \\
28 Sep 2000 & $10: 06 \mathrm{~h}$ & I, II, IV, V \\
25 Oct 2000 & $08: 17 \mathrm{~h}$ & I, II, III, IV \\
24 Nov 2000 & $08: 44 \mathrm{~h}$ & I, II, III, IV, V \\
13 Dec 2000 & $11: 13 \mathrm{~h}$ & I, II, III, V \\
11 Jan 2001 & $11: 03 \mathrm{~h}$ & I, II, III, IV, V \\
9 Feb 2001 & $10: 50 \mathrm{~h}$ & I, II, III, IV, V \\
12 Mar 2001 & $12: 00 \mathrm{~h}$ & I, II, III, V \\
9 Apr 2001 & $10: 53 \mathrm{~h}$ & I, II, III, V \\
24 May 2001 & $10: 38 \mathrm{~h}$ & I, II, III \\
21 Jun 2001 & $09: 35 \mathrm{~h}$ & I, II, III, V \\
23 Jul 2001 & $11: 43 \mathrm{~h}$ & I, III, V \\
\hline
\end{tabular}

their variation at station level, 3 more sediment cores were collected.

These 5 cores per station were brought back to the laboratory in a cooling box and stored either at $-20^{\circ} \mathrm{C}$ (the 2 cores for granulometric/water content and species diversity analyses) or at $-80^{\circ} \mathrm{C}$ (the 3 remaining cores for pigment content analysis) until further processing.

HPLC analysis. Pigment analysis was performed on 3 sub-samples cut from the 3 cores stored at $-80^{\circ} \mathrm{C}$ : a superficial layer between 0 and $2 \mathrm{~mm}$, an intermediate layer between 2 and $4 \mathrm{~mm}$ and a deep layer between 4 and $10 \mathrm{~mm}$. This sub-sampling involved the material gathered from November 2000 to July 2001. Before this period (May to October 2000) only the first $2 \mathrm{~mm}$ had been sub-sampled $(\mathrm{n}=180$ for the superficial layer, $\mathrm{n}=$ 111 for the intermediate layer and $n=111$ for the deep layer). These depths were chosen for 2 reasons: firstly, to sample the photic zone corresponding to the average depth for light penetration in fine sediment, that is $2 \mathrm{~mm}$ at most (Jørgensen \& Des Marais 1986, Kühl et al. 1994), and where microphytobenthic organisms are photosynthetically active; secondly, to obtain vertical profiles of pigment distributions in the first $10 \mathrm{~mm}$. The protocol for pigment extraction, HPLC equipment and elution programme were adapted from Mantoura \& Llewellyn (1983) as presented in Méléder et al. (2003a).

Qualitative analysis: After their elution, pigments were detected and characterised by measurement of their absorption spectra, expressed between 400 and $800 \mathrm{~nm}$ using a photodiode-array detector. Chromatograms were extracted at a wavelength of $440 \mathrm{~nm}$, and standards produced at the Laboratory of Marine Biology of the University of Nantes were used for pigment identification and quantification according to Brotas \& Plante-Cuny (1996). Results on samples gathered in October 2000 were not taken into account due to an instrument failure.

Quantitative analysis: Microphytobenthic biomass was estimated using chl a concentration (De Jonge 1980). In this study, pigment concentrations were reported in relation to the surface area sampled and expressed as $\mathrm{mg} \mathrm{m}^{-2}$ for each sediment layer, although several pigments were only named (not all respective standards were available). Quantification of chl a breakdown products was performed using fluorescence detection because of co-elution with some carotenoids. For some pigments, concentrations were summed: chl $a$ and its allomer and epimer, chlorophyll $C_{1}$ and $C_{1}+C_{2}$, fucoxanthin and its by-product (fucoxanthin-like), phaeopigments a (phaeophytins and phaeophorbides).

Vertical profiles: To quantify the amount of photosynthetically active biomass (PAB) belonging to the 
photic zone, biomass profiles were expressed for each layer against the total biomass in the first $10 \mathrm{~mm}$ : chl $\mathrm{a} / \mathrm{chl} a_{\text {tot }}$. On the other hand, vertical profiles of phaeopigments $a$ and fucoxanthin concentrations were expressed for the 3 layers analysed against chl $a$ in the same layer, phaeo $\mathrm{a} / \mathrm{chl} \mathrm{a}$ and fuco/chl $a$, to assess the physiological status of living cells in the photic zone and pigment lability with depth.

Granulometry analysis and water content. For each station, the first $2 \mathrm{~mm}$ of 1 of the 2 cores stored at $-20^{\circ} \mathrm{C}$ was sub-sampled for grain size analysis and water content $(\mathrm{n}=60)$. Sub-samples of sediments were dried at $60^{\circ} \mathrm{C}$ for $24 \mathrm{~h}$, and the ratio between the weight before and after drying gave the water content ( $\%$ of dry weight of sediment). About $1 \mathrm{~g}$ of this dry sediment was treated to analyse the grain size using a laser granulometer (Coulter LS 230). Processing the sediment before granulometric analysis was adapted from Baize (1988). This analysis allowed sediment textural groups to be defined through the relative abundance ( $\%$ volume) of mud $(\varnothing<63 \mu \mathrm{m})$ and sand $(63 \mu \mathrm{m}<\varnothing<2000 \mu \mathrm{m})$ according to the Udden-Wentworth scale (coarser grain sizes were not taken into account in this study). Data processing was performed using the GRADISTAT program (Blott \& Pye 2001).

Species diversity. To provide a control for the HPLC data, counting and taxonomic ranking of organisms were performed for each station on the first $2 \mathrm{~mm}$ of sediment from the second core stored at $-20^{\circ} \mathrm{C}$ ( $\mathrm{n}=$ 60). Determinations were carried out according to morphological criteria based on microscopic observations and reference works: Peragallo \& Peragallo (1897-1908), Hustedt (1927-1966, 1930), Van Der Werff \& Huls (1957-1974), Round et al. (1990) and Rincé (1993).

Cells were identified and counted, after the elimination of sediments, using a protocol adapted from Blanchard et al. (1988), allowing the separation of organic and mineral fractions of samples. This protocol was based on the centrifugation of sediments in a silica gel (Ludox HS-40) after an ultrasound treatment lasting $20 \mathrm{~min}$. The supernatant was recovered, rinsed and observed. If it was constituted only by diatoms, definitive preparations were made by mounting them in resin (Coumarone) after cleaning by cremation ( $2 \mathrm{~h}$ at $450^{\circ} \mathrm{C}$ ), whereas Euglenophyceae, Chlorophyceae and Cyanophyceae were identified and counted prior to cremation. In the case of a doubtful determination by photonic microscopy observations, scanning electron microscopy was used. A total of 200 to 500 diatom frustules were counted per slide to determine taxon quantities in samples. This was supplemented by identification of the life forms of observed taxa: planktonic, epipelic (benthic moving species), epipsammic (ben- thic fixed species on sediment grains) or epiphytic (fixed species on macroalgae or macrophytes) using knowledge from the literature and our own observations.

Statistical analysis. To assess temporal and spatial variability of microphytobenthic biomass (chl a), pigment ratio, sediment granulometry and water content, analyses of variance (ANOVA) were performed on logarithmically transformed data to adhere to the normality. Correlations of Spearman $\left(\mathrm{R}_{\mathrm{S}}\right)$ were carried out to study interactions between pigment concentrations, ratios, granulometry and water content using the whole data set measured in the photic zone.

\section{RESULTS}

\section{Qualitative pigment composition}

During the survey a total of 23 peaks were detected by the photodiode-array detector, corresponding to 23 pigments (Table 2) in a total of 402 sediment samples. Chlorophylls detected in samples were: chl a (Peaks 18 and VI), its allomer (Peaks 17 and VI') and epimer (Peak 19), chlorophyll $b$ (chl b) (Peaks 16 and V) and chlorophyll $C(\operatorname{chl} c)\left(c_{1}\right.$ : Peaks 2 and $\mathrm{II}_{;} C_{1}+C_{2}$ : Peaks 3 and III). Some breakdown products were also detected: chlorophyllide a (Peaks 1 and I), 3 phaeophorbides a (Peaks 6 and IV to IV"), 3 phaeophytins a (Peaks 22 and VII to VII") and 1 phaeophytin $b$ (Peak 20).

Identification and quantification of phaeopigments $a$ (phaeophorbides $a$ and phaeophytins a) were not possible by the photodiode-array chromatograms at $440 \mathrm{~nm}$. These pigments can be co-eluted with carotenoids, as is often the case in sediment samples (Brotas \& Plante-Cuny 1998). In this study, phaeophorbides a were co-eluted with fucoxanthin (Peak 4) and diadinoxanthin (Peak 7). Identification and quantification of phaeopigments a were thus performed using fluorescence chromatograms. Phaeophytin $b$ was also co-eluted but with chl a epimer (Peak 20). This co-elution did not permit the calculation of phaeophytin $b$ concentrations and was responsible for the shift of the 2 phaeophytin $b$ absorbance maxima to red wavelengths (626 and $670 \mathrm{~nm}$ respectively instead of $600 \mathrm{~nm}$ and $655 \mathrm{~nm}$, Table 2). At the end, note the detection of a pigment that seems to be a bacteriochlorophyll because of an absorbance maximum at $694 \mathrm{~nm}$ (Peak 15), on the boundary of the nearinfrared wavelength (Table 2).

Carotenoid pigments detected and identified were: fucoxanthin (Peak 4), fucoxanthin-like (Peak 5), diadinoxanthin (Peak 7), diatoxanthin (Peak 9), lutein (Peak 12) and $\beta$-carotene (Peak 23), whereas 6 carotenoids were not identified (Table 2). 
Table 2. Elution order, retention time (R.T.) and absorption wavelength maxima of chlorophyll and carotenoid pigments obtained by HPLC in sediment from Bourgneuf bay mudflat. Source: a, SCOR WG 78: Wright et al. (1991); b, Jeffrey (1972); c, SCOR WG 78: Mantoura \& Llewellyn (1983); d, Oelze (1985). Values in parentheses denote an inflection (a shoulder) in the absorption spectra

\begin{tabular}{|c|c|c|c|c|c|c|c|c|c|c|}
\hline \multirow{2}{*}{$\begin{array}{l}\text { Peak no. } \\
\text { at } 440 \mathrm{~nm} \\
1\end{array}$} & \multirow{2}{*}{$\begin{array}{l}\text { Peak no. in } \\
\text { fluorimetry }\end{array}$} & \multirow{2}{*}{$\begin{array}{c}\text { R.T. (min) } \\
(440 \mathrm{~nm}) \\
2.5\end{array}$} & \multirow{2}{*}{$\begin{array}{l}\text { Pigments } \\
\text { Chlorophyllide } a\end{array}$} & \multicolumn{6}{|c|}{ Absorption on wavelength maxima } & \multirow{2}{*}{$\begin{array}{c}\text { Source } \\
\mathrm{a}\end{array}$} \\
\hline & & & & 381 & 434 & & & 621 & 667 & \\
\hline 2 & II & 3.3 & $\mathrm{Chl} C_{1}$ & & 443 & & 581 & 631 & & $\mathrm{~b}$ \\
\hline 3 & III & 4.5 & $\mathrm{Chl} C_{1}+C_{2}$ & & 446 & & 584 & 634 & & $\mathrm{a}$ \\
\hline 4 & & 8.0 & Fucoxanthin & & 451 & $(472)$ & & & & $\mathrm{C}$ \\
\hline 5 & & 8.9 & Fucoxanthin-like & & 452 & (471) & & & & \\
\hline 6 & IV-IV" & 9.6 & Pheophorbide $a$ & & 410 & 505 & 536 & 612 & 669 & $\mathrm{a}$ \\
\hline 7 & & 10.3 & Diadinoxanthin & $(421)$ & 447 & 477 & & & & $\mathrm{C}$ \\
\hline 8 & & 10.6 & Unknown carotenoid 1 & & 441 & $(463)$ & & & & \\
\hline 9 & & 11.4 & Diatoxanthin & $(425)$ & 453 & 480 & & & & $\mathrm{a}$ \\
\hline 10 & & 11.7 & Unknown carotenoid 2 & $(421)$ & 444 & 472 & & & & \\
\hline 11 & & 11.0 & Unknown carotenoid 3 & & 448 & 471 & & & & \\
\hline 12 & & 12.7 & Lutein & $(423)$ & 448 & 477 & & & & $\mathrm{a}$ \\
\hline 13 & & 13.9 & Unknown carotenoid 4 & & 450 & 471 & & & & \\
\hline 14 & & 14.3 & Unknown carotenoid 5 & & 449 & 471 & & & & \\
\hline 15 & & 14.8 & Bacteriochlorophyll & 403 & 454 & & & & 694 & $\mathrm{~d}$ \\
\hline 16 & $\mathrm{~V}$ & 15.0 & $\mathrm{Chl} b$ & & 468 & & & 602 & 651 & $\mathrm{a}$ \\
\hline 17 & $\mathrm{VI}^{\prime}$ & 15.4 & Chl a allomer & 383 & 432 & & & 620 & 666 & \\
\hline 18 & VI & 15.8 & Chl a & 387 & 432 & & & 619 & 666 & $\mathrm{a}$ \\
\hline 19 & & 16.3 & Chl a epimer & 383 & 432 & & & 620 & 666 & \\
\hline 20 & & 16.6 & Pheophytin $b+\operatorname{chl} a$ & & 435 & & & 626 & 670 & $\mathrm{a}$ \\
\hline 21 & & 17.4 & Unknown carotenoid 6 & & 428 & 453 & & & & \\
\hline 22 & VII-VII" & 18.0 & Pheophytin a & & 410 & 505 & 538 & 609 & 666 & $\mathrm{a}$ \\
\hline 23 & & 19.7 & $\beta$-carotene & & 453 & 480 & & & & $\mathrm{C}$ \\
\hline
\end{tabular}

\section{Pigment origins}

The association of accessory pigments, chl $C_{\text {, fuco- }}$ xanthin and diadinoxanthin, occurred in the 402 samples analysed, in addition to the ubiquitous chl $a$. This is characteristic of both Bacillariophyceae (diatoms) and golden-brown flagellates such as Prymnesiophyceae (Jeffrey \& Vesk 1997). This pigment set could be completed by the occurrence of diatoxanthin, a minor pigment of these same algal groups, detected in more than $90 \%$ of samples. However, microscopic observations revealed that this pigment association was essentially due to diatoms, which represented $97 \%$ of counted cells ( $\mathrm{n}=27570$ ), while no flagellates were observed. Euglenophyceae, Chlorophyceae and Cyanophyceae were also observed by microscopy in sediments only from August to October 2000. These taxa represented respectively $2.5,0.5$ and less than $0.01 \%$ of the whole counted cells, although Euglenophyceae could domi- nate some assemblages with more than $80 \%$ of the counted cells of samples involved. These observations by microscopy were confirmed by the detection of chl $b$, a biomarker of Euglenophyceae and/or Chlorophyceae occurrence, which was found only in samples collected between August and October 2000. The occurrence of Cyanophyceae was not confirmed by HPLC analyses obtained with the Mantoura and Llewellyn (1983) protocol (Le Bris et al. 1998) due to the co-elution of lutein and zeaxanthin, the latter being a biomarker of these photosynthetic organisms. The occurrence of these taxa was too sporadic to use them as biomarkers of organic pollution of the Bourgneuf Bay mudflat.

On the other hand, phaeophytin $b$ was detected more often (30\% of analysed samples) than chl $b$. This breakdown product mainly occurred in May 2000 and from January to May 2001 when Euglenophyceae and/or Chlorophyceae were not observed by microscopy examination (Table 3). Lutein appeared in the

Table 3. Phaeophytin $b(+)$ and lutein $(\bullet)$ detection by the photodiode-array detector during the survey. Each character indicates a station where pigments were detected

\begin{tabular}{|c|c|c|c|c|c|c|c|c|c|c|c|c|c|}
\hline May 00 & Jun 00 & Jul 00 & Aug 00 & Sep 00 & Nov 00 & Dec 00 & Jan 01 & Feb 01 & Mar 01 & Apr 01 & May 01 & Jun 01 & Jul 01 \\
\hline $\begin{array}{l}+++ \\
000\end{array}$ & ++ & + & $\stackrel{+}{\bullet}$ & - & ๑) & + & $\begin{array}{l}+++++ \\
00000\end{array}$ & ++++t & ++++ & $\stackrel{++++}{000}$ & $\stackrel{+++}{\bullet}$ & ++ & $\stackrel{+}{\bullet}$ \\
\hline
\end{tabular}


same samples as phaeophytin $b$, but also in sediment sampled in November and December 2000 (Table 3). These 2 pigments could be linked to an import of macrophytic debris (Brotas \& Plante-Cuny 1998), which may be related to high hydrodynamism conditions mainly during winter months. This is confirmed by sediment granulometry observed during the survey at the mesoscale, showing a low mud fraction at the same period as the phaeophytin $b$ and lutein detection (December to February) due to resuspension of the finest particles in the water column (Table 4).

These results suggest that the main origin of pigment in sediments was autochthonous, with a poor input from the water column. This was confirmed by the determination of diatom life forms observed in sediment. Only 5 out of the 89 observed taxa were planktonic (namely: Odontella regia, Nitzschia closterium, N. fasciculata, Grammatophora serpentina and Lithodesium undulatum), representing less than $10 \%$ of the counted cells during the survey and found in less than $4 \%$ of the samples observed $(n=60)$. Moreover, the 17 most observed taxa, occurring in more than $50 \%$ of samples and representing $69 \%$ of the counted cells, were mainly epipsammic (11 taxa: Plagiogrammopsis vanheurckii, Amphora spp., Achnanthes hauckiana, Achnanthes lanceolata var. elleptica, Thalassiosira decipiens, Cymatosira belgica, Plagiogramma tenuissimum, Cocconeis hoffmanni, Biremis ambigua, Fragilaria pinnata and Lyrella pseu-

Table 4. Characteristics of sediment samples from the Bourgneuf Bay mudflat for the 15 mo of the survey and the 5 stations (mean values $\pm \mathrm{SD}$ ). DW = dry weight; boldface values are the maxima; underlined values are the minima

\begin{tabular}{|lcll|}
\hline Months & $\begin{array}{c}\text { Median grain } \\
\text { size }(\mu \mathrm{m})\end{array}$ & \% mud & $\begin{array}{c}\text { \% water } \\
\text { (of DW) }\end{array}$ \\
\hline May 00 & $85.48 \pm 22.36$ & $35.93 \pm 13.40$ & $38.29 \pm 5.75$ \\
Jun 00 & $58.95 \pm 49.93$ & $58.25 \pm 35.83$ & $59.20 \pm 9.02$ \\
Jul 00 & $65.55 \pm 40.07$ & $49.20 \pm 25.89$ & $49.07 \pm 15.52$ \\
Aug 00 & $\underline{8.29 \pm 0.29}$ & $\mathbf{9 6 . 0 7} \pm \mathbf{1 . 9 4}$ & $64.77 \pm 4.86$ \\
Sep 00 & $30.85 \pm 30.05$ & $77.98 \pm 21.72$ & $50.73 \pm 10.43$ \\
Oct 00 & $41.47 \pm 27.63$ & $63.80 \pm 22.11$ & $46.48 \pm 11.62$ \\
Nov 00 & $46.86 \pm 31.28$ & $62.63 \pm 22.75$ & $42.59 \pm 7.34$ \\
Dec 00 & $60.26 \pm 37.14$ & $55.88 \pm 21.39$ & $46.02 \pm 5.62$ \\
Jan 01 & $75.82 \pm 38.22$ & $43.30 \pm 23.27$ & $41.23 \pm 11.43$ \\
Feb 01 & $\mathbf{9 7 . 7 6} \pm \mathbf{2 0 . 2 4}$ & $\underline{29.00 \pm 4.30}$ & $\underline{31.64 \pm 6.89}$ \\
Mar 01 & $47.04 \pm 30.80$ & $60.23 \pm 22.44$ & $53.15 \pm 11.28$ \\
Apr 01 & $53.01 \pm 38.85$ & $55.60 \pm 22.83$ & $49.20 \pm 16.42$ \\
May 01 & $45.65 \pm 47.48$ & $67.10 \pm 33.20$ & $51.02 \pm 18.22$ \\
Jun 01 & $61.52 \pm 48.31$ & $56.14 \pm 31.97$ & $40.13 \pm 11.01$ \\
Jul 01 & $\underline{7.52 \pm 0.38}$ & $\mathbf{9 4 . 1 5} \pm \mathbf{0 . 7 8}$ & $\mathbf{7 3 . 4 3} \pm \mathbf{0 . 5 5}$ \\
Stations & & & \\
I & $\underline{31.85 \pm 33.37}$ & $\mathbf{7 4 . 7 9} \pm \mathbf{2 3 . 2 6}$ & $\mathbf{6 0 . 2 6} \pm \mathbf{1 1 . 4 0}$ \\
II & $\mathbf{7 7 . 8 2} \pm \mathbf{3 1 . 1 4}$ & $\underline{42.50 \pm 17.43}$ & $44.65 \pm 10.34$ \\
III & $\mathbf{7 6 . 5 7} \pm \mathbf{3 3 . 8 9}$ & $\underline{40.97 \pm 22.68}$ & $42.24 \pm 10.25$ \\
IV & $52.00 \pm 31.42$ & $59.23 \pm 25.93$ & $42.05 \pm 14.13$ \\
V & $36.73 \pm 38.90$ & $74.50 \pm 25.21$ & $\underline{41.27 \pm 10.76}$ \\
\hline
\end{tabular}

dony). The 6 remaining taxa were epipelic (Navicula perminuta, Navicula spartinetensis, Navicula anglica and Fallacia tenera) and epiphytic (Odontella aurita and Cocconeis scutellum). All these taxa were small, with a size less than $30 \mu \mathrm{m}$, except the 2 epiphytic taxa.

\section{Photosynthetically active biomass (PAB)}

Chl a concentration measured by HPLC in the photic zone $(0$ to $2 \mathrm{~mm})$ ranged from $12.2 \pm 8.6( \pm \mathrm{SD})$ in

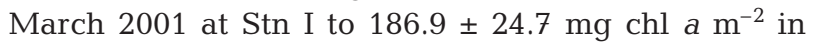
August 2000 at Stn III (Fig. 2a). Temporal variability was significant $(\mathrm{p}<0.001, \mathrm{n}=180$ ) but did not follow a seasonal cycle: higher values were measured in spring 2000, whereas the lowest values were measured in sediments sampled 1 yr later. There was also a spatial variability ( $p<0.001, n=180)$ : lower values were measured at Stn I ( $\left.35 \pm 16.4 \mathrm{mg} \mathrm{chl} \mathrm{a} \mathrm{m}^{-2}\right)$ and the greatest at Stn III (89.4 $\left.\pm 45.5 \mathrm{mg} \mathrm{chl} \mathrm{a} \mathrm{m}^{-2}\right)$ (Fig. 2b). These results suggest the predominance of a spatial variability of PAB at the mesoscale over a seasonal one. The distribution of the biomass data at the microscale, illustrated by standard deviation (SD), showed variability between sampling units for a given station in a given month (Fig. 2a). This variability increased with higher biomass (>50 mg chl a m $\mathrm{m}^{-2}$ ).

\section{PAB, sediment characteristics and species communities}

The predominance of a spatial variability of PAB reflected spatial changes in abiotic factors like sediment characteristics and emersion period (Table 4). In fact, $\mathrm{PAB}$ was higher at mid-transect stations, constituted by coarser sediments, than at lower- and uppertransect stations (I and V), constituted by finer sediments, especially during summer (Fig. 2b, Table 4). This was confirmed by the negative correlation between PAB and mud fraction (Table 5). Water content also had an influence on PAB spatial distribution $\left(\mathrm{R}_{\mathrm{s}}=-0.48 ; \mathrm{n}=180 ; \mathrm{p}<0.001\right)$, which is linked not only to sediment granulometry but also to the duration of the emersion period. Water content decreasing from Stn I to Stn V (Table 4) showed the influence of sediment de-watering during the emersion period, between the beginning and the end of the sampling programme. It could result in changes in microphytobenthic chl a concentration due to an increase in the sediment wet bulk density (Perkins et al. 2003).

However, major changes in PAB were due to changes in diatom abundance because of the positive

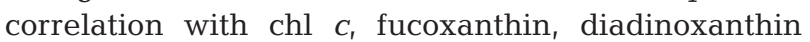
and diatoxanthin concentrations, which also correlated 

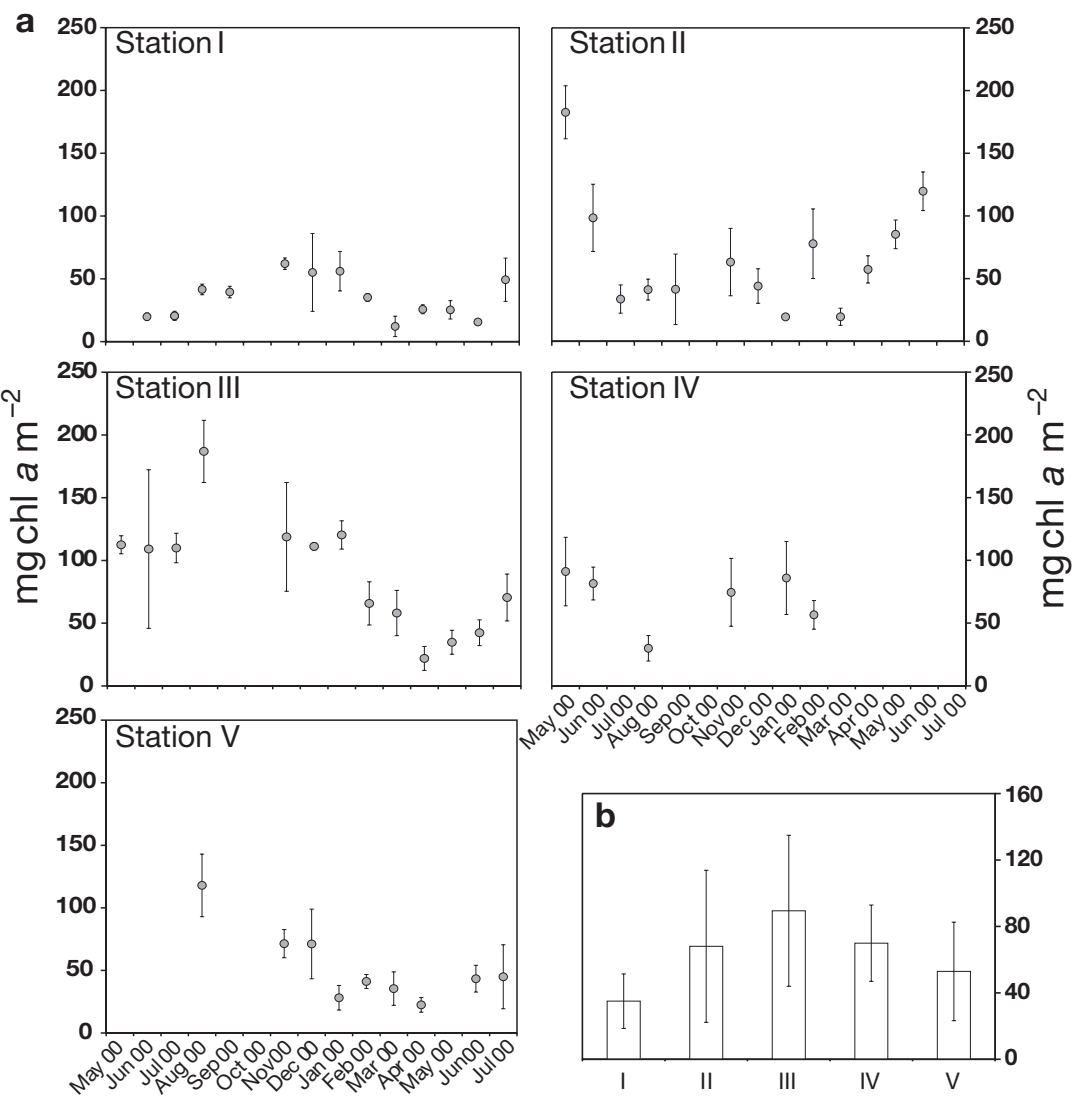

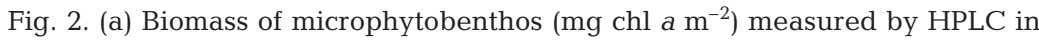
the photic zone ( 0 to $2 \mathrm{~mm}$ ) of the 3 sediment cores sampled between May 2000 and July 2001 at the 5 stations (I to V); (b) spatial variability of averaged biomass for the 15 mo in the photic zone along the transect amphyoxis and Scolioneis tumida, known for their adaptation to a muddy environment (Hamels et al. 1998, Paterson \& Hagerthey 2001). Contrary to the expected results, these species were not responsible for the highest biomass (Fig. 2).

\section{Biomass vertical distribution}

From December 2000 to July 2001, the biomass vertical distribution followed a similar trend: biomass decreased with depth and showed vertical profiles, more or less marked depending on the sample. The greatest amplitude occurred in July 2001 (Fig. 3) when sediment mud content was at its highest level (Table 4). The amount of PAB against total biomass in the first $10 \mathrm{~mm}\left(\mathrm{chl} a_{\text {tot }}\right)$ varied between $28 \pm 1 \%( \pm \mathrm{SD})$ in February 2001 at Stn V and $68 \pm 14 \%$ in July 2001 at Stn I. These results suggest a relationship with grain size illustrated by biomass accumulation in the photic zone compared to the deeper layers, except in November 2000 and in some isolated samples where biomass increased with depth (Fig. 3). with mud fraction (Table 5). Diatom communities responsible for this $\mathrm{PAB}$ were mainly constituted by the 17 commonly occurring taxa. On the other hand, Stns I and V were colonised during summer, when mud content increases, by large and motile taxa like Plagiotropis vitrea, Pleurosigma aestuari, Staurophora

\section{Chl a breakdown products}

Chlorophyllide $a$, produced by senescent cells and/ or by chlorophyllase activity (Jeffrey 1974, Jeffrey \& Hallegreaff 1987), was detected during this survey in less than $45 \%$ of analysed samples. In the photic zone

Table 5. Significant Spearman correlations $\left(\mathrm{R}_{\mathrm{s}}\right)$ between pigment concentrations measured by HPLC and mud fraction in the first $2 \mathrm{~mm}$ (photic zone) of sediment sampled from the Bourgneuf Bay mudflat between May 2000 and July 2001 (n = 180)

\begin{tabular}{|c|c|c|c|c|c|}
\hline & Chlorophyll $C$ & Diadinoxanthin & Diatoxanthin & Chlorophyll a & $\%$ mud \\
\hline Fucoxanthin & $\begin{array}{c}0.89 \\
(p<0.001)\end{array}$ & $\begin{array}{c}0.89 \\
(\mathrm{p}<0.001)\end{array}$ & $\begin{array}{c}0.72 \\
(p<0.001)\end{array}$ & $\begin{array}{c}0.94 \\
(\mathrm{p}<0.001)\end{array}$ & $\begin{array}{c}-0.38 \\
(\mathrm{p}<0.01)\end{array}$ \\
\hline Chlorophyll $C$ & & $\begin{array}{c}0.93 \\
(\mathrm{p}<0.001)\end{array}$ & $\begin{array}{c}0.70 \\
(\mathrm{p}<0.001)\end{array}$ & $\begin{array}{c}0.93 \\
(p<0.001)\end{array}$ & $\begin{array}{c}-0.64 \\
(\mathrm{p}<0.001)\end{array}$ \\
\hline Diadinoxanthin & & & $\begin{array}{c}0.56 \\
(\mathrm{p}<0.001)\end{array}$ & $\begin{array}{c}0.87 \\
(\mathrm{p}<0.001)\end{array}$ & $\begin{array}{c}-0.52 \\
(p<0.001)\end{array}$ \\
\hline Diatoxanthin & & & & $\begin{array}{c}0.73 \\
(p<0.001)\end{array}$ & $\begin{array}{c}-0.31 \\
(\mathrm{p}<0.05)\end{array}$ \\
\hline Chlorophyll a & & & & & $\begin{array}{c}-0.51 \\
(p<0.001)\end{array}$ \\
\hline
\end{tabular}




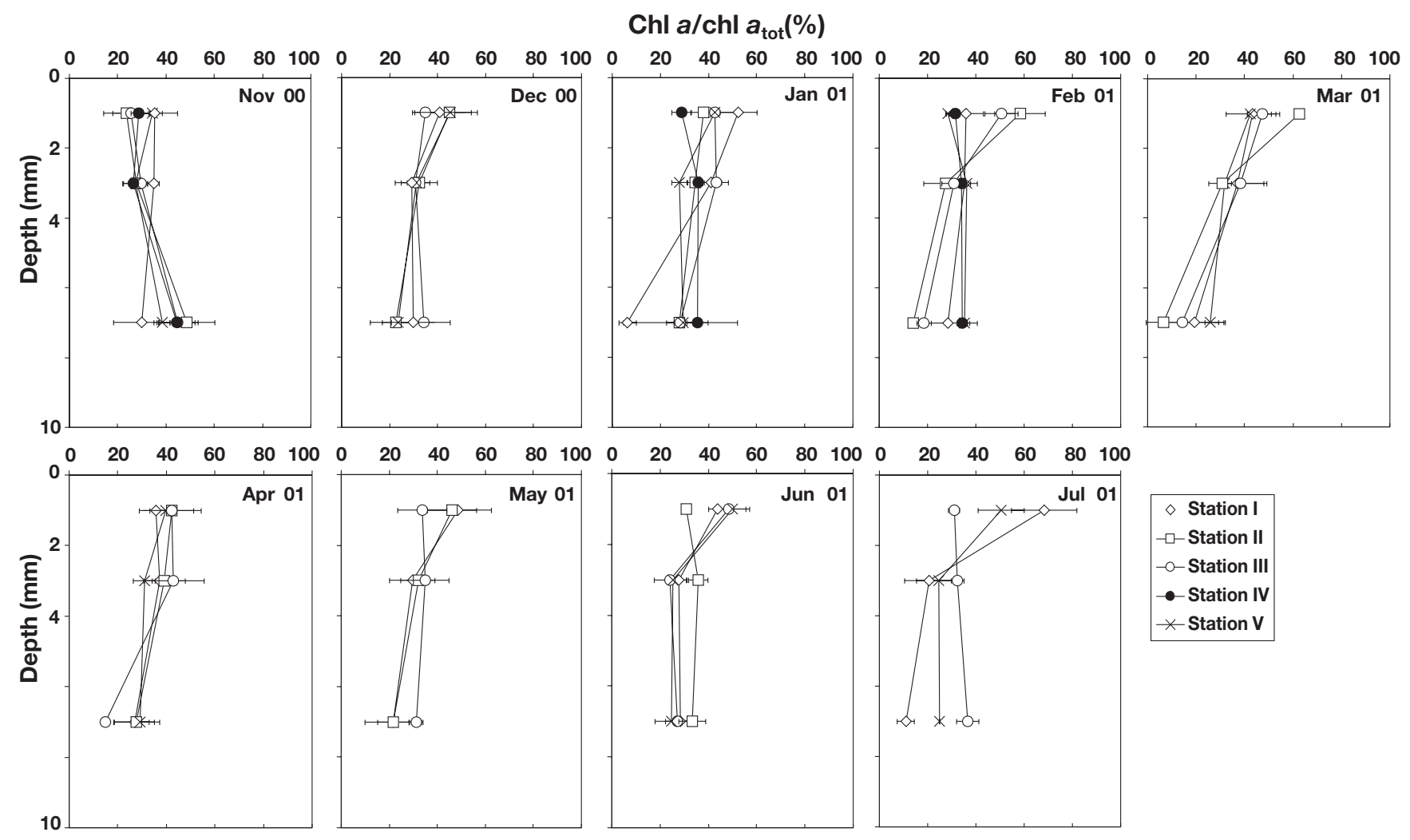

Fig. 3. Vertical profile of $\mathrm{chl} \mathrm{a/chl} a_{\text {tot }}$ ratio: distribution of microphytobenthic biomass within 3 layers $(0$ to $2 \mathrm{~mm}=$ the photic zone; 2 to $4 \mathrm{~mm}$; to $10 \mathrm{~mm}$ ) in each station between November 2000 and July 2001. Horizontal bars denote SD

of the Bourgneuf Bay mudflat, this breakdown product represented only a chl a fraction of $0.05 \pm 0.04$ with an average concentration of $3.1 \pm 2.8 \mathrm{mg} \mathrm{m}^{-2}$. This illustrates the good physiological status of microphytobenthic cells responsible for photosynthesis, confirmed by the low $\mathrm{chl} c / \mathrm{chl} a$ ratios (Lucas \& Holligan 1999), which did not exceed 0.08 (Table 6). Phaeopigments a (phaeophorbides $a+$ phaeophytins $a$ ), detected in more than $90 \%$ of samples, were the most abundant breakdown products in sediments. Phaeophorbides $a_{\text {, }}$ considered by several authors to be useful markers for

Table 6. Chl c/chl a ratio calculated using chlorophylls $a$ and $C$ concentrations in the photic zone measured by HPLC during the survey (mean values $\pm \mathrm{SD}$ )

\begin{tabular}{|lclc|}
\hline Month & Chl $c /$ chl a ratio & Month & Chl $c /$ chl $a$ ratio \\
\hline May 00 & $0.06 \pm 0.02$ & Jan 01 & $0.06 \pm 0.01$ \\
Jun 00 & $0.05 \pm 0.01$ & Feb 01 & $0.08 \pm 0.02$ \\
Jul 00 & $0.06 \pm 0.005$ & Mar 01 & $0.07 \pm 0.03$ \\
Aug 00 & $0.05 \pm 0.003$ & Apr 01 & $0.07 \pm 0.02$ \\
Sep 00 & $0.03 \pm 0.01$ & May 01 & $0.07 \pm 0.01$ \\
Nov 00 & $0.04 \pm 0.004$ & Jun 01 & $0.06 \pm 0.007$ \\
Dec 00 & $0.04 \pm 0.01$ & Jul 01 & $0.06 \pm 0.005$ \\
\hline
\end{tabular}

intertidal microphytobenthos grazing by meio- and macrofauna (Abele-Oeschger \& Theede 1991, PlanteCuny et al. 1993, Buffan-Dubau et al. 1996, Pastoureaud et al. 1996, Cartaxana et al. 2003; but see Ford \& Honeywill 2002), showed greater concentrations than phaeophytin $a$, a degraded pigment generally linked to microbial activity (Bianchi et al. 1991). Phaeophorbides a represented $61 \pm 3 \%$ of the chl $a$ breakdown products in the photic zone.

Concentrations of phaeopigments a (phaeophorbides $a+$ phaeophytins a) measured by HPLC in the first $2 \mathrm{~mm}$ of sediment ranged from $0.8 \pm 0.1$ (February 2001, Stn I) to $16.02 \pm 6.1 \mathrm{mg} \mathrm{m}^{-2}$ (August 2000, Stn IV). However, concentrations provided no information about grazing or microbial activities: the phaeo $\mathrm{a} / \mathrm{chl} a$ ratio was more informative (Cariou-Le Gall \& Blanchard 1995). In the photic zone, the lowest ratio values $(<0.1)$ were detected mainly from November 2000 to February 2001 and in July 2001, whereas the highest $(>0.2)$ occurred during the other periods of the survey (Fig. 4), including the period before November 2000 (not shown). This suggests a higher degradation of chl a into phaeopigments in spring/summer, mainly due to grazing activity. Spatially, the lowest ratios were detected in stations with the highest chl a concentra- 


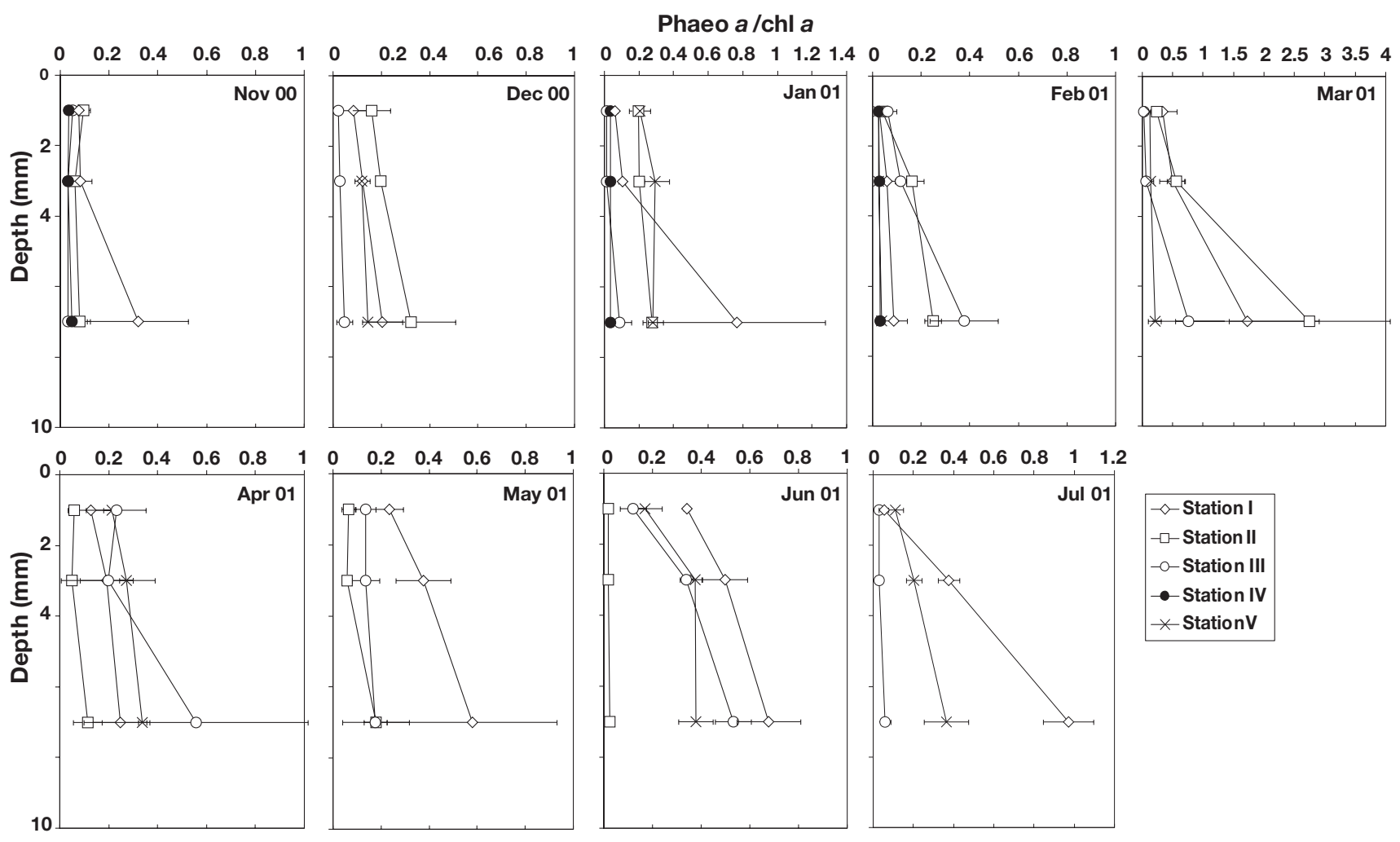

Fig. 4. Vertical profile of phaeo a/chl a ratio in the 3 layers ( 0 to $2 \mathrm{~mm}=$ the photic zone; 2 to $4 \mathrm{~mm} ; 4$ to $10 \mathrm{~mm}$ ) in each station between November 2000 and July 2001. Horizontal bars denote SD

tions (Stns II and III), and, conversely, the highest ratios were detected in stations with the lowest chl a concentrations (Stn I). This was linked to an accumulation of grazed cells in the photic zone of stations exhibiting the finest sediments and lowest biomass. It was confirmed by a positive correlation between phaeo a/chl a ratios and mud fraction $\left(\mathrm{R}_{\mathrm{s}}=0.61 ; \mathrm{p}<0.001\right)$. Moreover, the increase in mud content in summer (Table 4) suggests a correlation during this period between the deposition phenomenon (due to low hydrodynamism), responsible for phaeopigments a accumulation, and high grazing activity, responsible for an increase in phaeophorbides a.

\section{Vertical distribution}

Profiles showed an increase in phaeo a/chl a ratios with depth at each station (ANOVA; $\mathrm{p}<0.001$ ), except in November 2000 for which vertical variability was not significant (ANOVA; $\mathrm{p}=0.2$ ). Ratios could reach very high values according to depth in spring/summer, especially in March 2001 at Stns I and II where concentrations of phaeopigments a represented respectively $1.73 \pm 1.18$ and $2.64 \pm 0.91$ times the chl a con- centration in the deep layer (4-10 mm; Fig. 4). This illustrates a gradient of dead or broken benthic microalgae by grazing along the depth due to passive burying. This gradient was less marked in autumn/ winter because of a stronger hydrodynamism responsible for a high level of sediment mixing.

\section{Fucoxanthin}

Concentration values of the major accessory pigment of diatoms measured in the first $2 \mathrm{~mm}$ of sediment ranged from $3.8 \pm 2.5$ (March 2001, Stn I) to $63.2 \pm$ $14.2 \mathrm{mg} \mathrm{m}^{-2}$ (August 2000, Stn III). As for phaeopigments $a$, the fuco/chl a ratio was more informative about the physiological status of microphytobenthos, production of fucoxanthin being linked to low light intensity (irradiance) (Lohr \& Wilhelm 1998, Brotas \& Plante-Cuny 2003). This ratio in the photic zone varied, not spatially (ANOVA; $\mathrm{p}=0.3$ ), but temporally (AN$\left.\mathrm{OVA}_{i} \mathrm{p}<0.01\right)$. Ratio values increased in spring/summer when light intensity was highest (Fig. 5). Thus, like the phaeo a/chl a ratio, the lower values (0.30) were measured from November 2000 to February 2001, whereas the highest were measured in the other 


\section{Fuco/chl a}

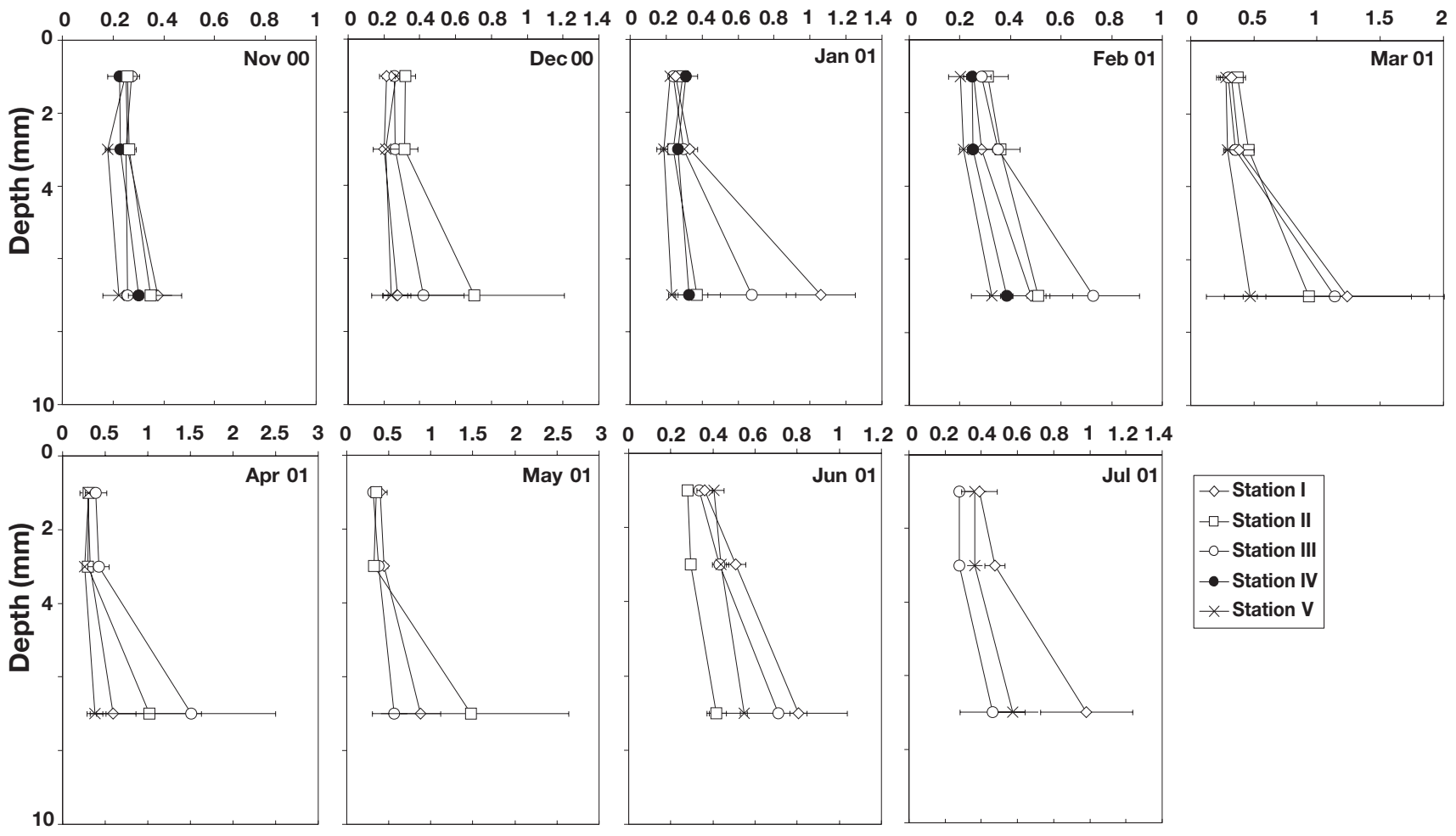

Fig. 5. Vertical profile of fuco/chl a ratio in the 3 layers ( 0 to $2 \mathrm{~mm}=$ the photic zone; 2 to $4 \mathrm{~mm} ; 4$ to $10 \mathrm{~mm}$ ) in each station between November 2000 and July 2001. Horizontal bars denote SD

months of the survey, without exceeding 0.45 (Fig. 5). These results did not permit the use of the fuco/chl $a$ ratio as a biomarker of microphytobenthos photoadaptation because of the disagreement with the expected results, i.e. an increase in its value during periods of low light intensity.

\section{Vertical distribution}

Vertical profiles of fuco/chl a ratio increased with depth (Fig. 5). These profiles were less marked during November 2000 to February 2001, like the phaeo a/ $\mathrm{chl}$ a ratio, due to a higher hydrodynamism in winter. In spring/summer, fucoxanthin content exceeded chl a content in the deeper layer (ratio > 1.00). Increasing fuco/chl $a$ values with depth illustrated the lower lability of fucoxanthin compared to chl a (Fig. 5). Chl a was degraded into phaeopigments mainly by grazing, whereas fucoxanthin did not undergo alteration (Fig. 5). This allowed the fuco/chl a ratio to be used in this study as a biomarker of grazing activity in the photic zone, rather than a biomarker of photoadaptation. This use was confirmed by a positive correlation $\left(\mathrm{R}_{\mathrm{s}}=0.52 ; \mathrm{n}=180 ; \mathrm{p}<0.001\right)$ between both ratios in the first $2 \mathrm{~mm}$ (phaeo $\mathrm{a} / \mathrm{chl} \mathrm{a}$ and fuco/chl $a$ ). Thus, like phaeo $a / c h l a$, fuco/chl a vertical profiles illustrated a gradient of dead or broken benthic microalgae along the depth.

\section{DISCUSSION}

\section{Pigments as biomarkers}

Allochthonous vs. autochthonous

As in similar coastal ecosystems, microphytobenthos assemblages of the Bourgneuf Bay mudflat were largely dominated by diatoms characterised by the following pigment set: chl $c$, fucoxanthin, diadinoxanthin and diatoxanthin (Mackey et al. 1996, Brotas \& PlanteCuny 1998, Schlüter et al. 2000, Brotas \& Plante-Cuny 2003). The dominance by this algal group was confirmed by the average values of the fuco/chl a ratio, ranging in the photic zone during the survey from 0.2 to 0.4 (Mackey et al. 1996, Schlüter et al. 2000, Brotas $\&$ Plante-Cuny 2003). The use of pigment ratios, however, must be carried out with caution because of the large number of environmental and physiological fac- 
tors affecting them (Lucas \& Holligan 1999). In fact, a variation in ratio values could be endogenous and linked to the ecophysiological status of some species, like the implementation of a photoadaptation to high or low irradiance (Brotas \& Plante-Cuny 2003) or cell senescence (Jeffrey 1974, Plante-Cuny et al. 1993). A second source of variation is environmental, such as deposit and suspension feeders whose grazing forms phaeopigments (Buffan-Dubau et al. 1996, Pastoureaud et al. 1996, Brotas \& Plante-Cuny 1998, Cartaxana et al. 2003) or an import of several non-degraded carotenoids, originating from macrophyte debris (Brotas \& Plante-Cuny 1998). Thus the use of pigment ratio to discuss microalgal assemblage structure must be completed by other analyses. In this study, the dominance of diatoms among microphytobenthic assemblages was confirmed by microscopic observations and correlation between biomarker pigment concentrations.

Among accessory pigments identified in sediments of the Bourgneuf Bay mudflat, several were not extracted from diatoms, namely chl $b$, its breakdown product phaeophytin $b$ and lutein. These 3 pigments could be related to various sources: living Euglenophyceae, Chlorophyceae or macrophyte debris for chl $b$, detrital material from Euglenophyceae, Chlorophyceae or macrophytes for phaeophytin $b$ and only Chlorophyceae and macrophyte debris for lutein (Abele-Oeschger \& Theede 1991, Bianchi et al. 1991, Wright et al. 1991, Brotas \& Plante-Cuny 1998). The presence of these pigments could originate from sinking phytoplankton cells or macrophytic debris, as deposition is favoured during summer due to lower hydrodynamism. However, in this study, chl $b$ originated mainly from microalgae because it was detected only in summer samples when Euglenophyceae and/or Chlorophyceae were observed by microscopy. Moreover, the low numbers of planktonic species observed on the mudflat, especially during the low hydrodynamism period, suggest a limited contribution of microalgae from the water column or a limited phytoplanktonic production in this ecosystem.

The unique input of macrophyte debris from the overlying water occurred during the winter/spring 2000-2001 period, when phaeophorbide $b$ and lutein were detected. No Euglenophyceae and/or Chlorophyceae were observed, and no chl $b$ was detected. This import of macrophyte debris could also be a source of phaeopigments a (phaeophorbides and phaeophytins a) and chlorophyllide $a$ for the mudflat (Brotas $\&$ Plante-Cuny 1998). However, the fact that these degraded pigments detected in sediment of Bourgneuf Bay were not linked to lutein and phaeophytin $b$ occurrence confirmed the main autochthonous/microphytobenthic origin for these breakdown products of chl $a$.
This supports an autochthonous source for microalgal cells and biomass, particularly the PAB in the sediments of the Bourgneuf Bay mudflat, due to microphytobenthos assemblages.

\section{Chl a breakdown products - grazing activity}

A variety of these pigments was detected during this study corresponding to varying alteration processes of chl a: 1 chlorophyllide $a, 3$ phaeophorbides $a$ and 3 phaeophytins $a$. These results are similar to those of Cariou-Le Gall \& Blanchard (1995) in the bay of Marennes-Oléron and of Buffan-Dubau et al. (1996) in the bay of Arcachon. Brotas \& Plante-Cuny (1998) detected 9 phaeophorbides $a$ and 3 phaeophytins $a$ in the first $5 \mathrm{~mm}$ of sediment of the Tagus estuary mudflat.

In the sediments of the Bourgneuf Bay mudflat, phaeopigments $a$ and chlorophyllide $a$ in the photic zone did not show a high concentration compared to chl $a$, phaeopigments representing a maximum fraction of $30 \%$ of the undegraded form (phaeo a/chl $a$ ratio 100 ) and chlorophyllide $a$, about $5 \%$. Such values are lower than those found in the first $5 \mathrm{~mm}$ of sediment of the Marenne-Oléron mudflat, where phaeopigments a represented on average more than $40 \%$ of the sum of chl $a$ and phaeopigments a (Cariou-Le Gall \& Blanchard 1995). Lucas \& Holligan (1999) reported greater proportions in the first $2 \mathrm{~mm}$ of the sediment from Westerschelde estuary: sandy stations had similar concentrations of chl $a$ and phaeophorbides $a$, whereas muddy stations showed phaeophorbides a concentrations 2-fold higher than chl a concentrations. Results obtained in the Bourgneuf Bay mudflat suggest a weaker degradation of microphytobenthos compared to similar mudflats.

Despite these differences, the results of chl a breakdown products, analysed by HPLC, from the Bourgneuf Bay mudflat confirm the observations of several authors (Cariou-Le Gall \& Blanchard 1995, BuffanDubau et al. 1996, Brotas \& Plante-Cuny 1998, Lucas \& Holligan 1999, Cartaxana et al. 2003): phaeophorbides $a$ are always measured in higher concentrations than phaeophytins $a$ and chlorophyllide $a$. This suggests that grazing activity in the photic zone was stronger than microbial activity and that the physiological status of the microphytobenthic community remained good throughout the survey, confirmed by low chl $\mathrm{C} /$ $\mathrm{chl}$ a ratios. The period of the highest grazing pressure on microphytobenthos was when the phaeo $a / \mathrm{chl} a$ ratio was maximal, from March to June 2001. This period corresponds to a lower microphytobenthos PAB and indicates that chl a had been degraded into phaeophorbides a by grazing. At the same time, sev- 
eral authors have shown a relationship between lower microphytobenthic biomass and greater macro- and meiofauna abundance (Buffan-Dubau et al. 1996, Lucas \& Holligan 1999, Pinckney et al. 2003). This occurred mainly in spring, in contrast to winter, when high biomass is associated with low macro- and meiofauna abundance (Pinckney et al. 2003). Despite a lack of data on the Bourgneuf Bay mudflat benthic invertebrate community structure (but see Gruet 1972, 1977), this community probably shows the same characteristics as those observed on temperate intertidal mudflats, that is a Macoma balthica community, often associated with high biomass and density (Bachelet et al. 1997). In this study, the quantity of phaeopigments $a$ compared to chl a suggests a lower biomass and/or grazing rate of zoobenthos than in similar mudflats. To confirm these interactions between microphytobenthos structure and a reduced grazing activity, a survey of abundance, biomass and grazing rate of zoobenthos in the Bourgneuf Bay mudflat would be necessary.

Like the phaeo a/chl a ratio, fuco/chl a showed a seasonal trend in the photic zone: values were higher during spring/summer than in autumn/winter. This trend was unexpected: values should have been higher in autumn/winter (Lohr \& Wilhelm 1998, Brotas \& PlanteCuny 2003). The difference between the observations and expected results was linked to the greater effect of the grazing activity during spring/summer than the low light effect during autumn/winter. This also illustrates the lower lability of fucoxanthin compared to chl $a_{1}$ in accordance with results found by Brotas \& PlanteCuny (1998) and Lucas \& Holligan (1999), although Abele-Oeschger \& Theede (1991) reported a similar half-life for these 2 pigments and Cariou-Le Gall \& Blanchard (1995) found that chl a was more conserved than fucoxanthin. The lower lability of fucoxanthin is confirmed by the fact that carotenoids have no enzymatic degradation pathway of comparable importance to that of chlorophylls (Porra et al. 1997).

\section{Spatial and temporal variability of microphytobenthos PAB}

In Bourgneuf Bay, chl a concentrations measured in the photic zone, estimating the PAB of the sediment mudflat from May 2000 to July 2001, were in agreement with those found in similar ecosystems whether the measurements were made in the first 2 or $10 \mathrm{~mm}$ of sandy or muddy sediment (Table 7). PAB showed temporal variability but did not follow a seasonal cycle, whereas meso-spatial variability was linked to abiotic factors (Saburova et al. 1995). Usually, mixed sediments (muddy sand to fine sand) as observed on the Bourgneuf Bay mudflat at Stns II to IV are colonised by complex and resilient microbenthic communities, constituted by a large fraction of small epipsammic life forms that do not form visible biofilms well (Hamels et al. 1998, Paterson \& Hagerthey 2001). This is confirmed by the high occurrence and abundance of small epipsammic taxa in microphytobenthos assemblages of the Bourgneuf Bay mudflat throughout the survey. These taxa are monoraphid diatoms, such as Cocconeis hoffmanni and Achnantes hauckiana, and araphid diatoms, such as Cymatosira belgica and Plagiogrammopsis vanheurckii, and are often observed in mixed intertidal sediments (Colijn \& Dijkema 1981, De Jonge \& Van Beusekom 1992, Riethmüller et al. 2000, Paterson \& Hagerthey 2001). These assemblages are adapted to a continuous regime of disturbance in the top layers of sediment and vary with a low pronounced seasonality (Hamels et al. 1998, Paterson \& Hagerthey 2001). The greater instability of these mixed areas is illustrated by the fact that the proportion of epipsammic species resuspended in the water column is higher than the proportion of epipelic species (De Jonge 1985).

In contrast, sheltered intertidal muddy areas are characterised by high microphytobenthos biomass, favoured by an accumulation of nutrients and the stability of the sediment increasing with EPS secretion (Riethmüller et al. 2000, Paterson \& Hagerthey 2001). Muddy sediment, colonised by large epipelic life forms, appears to be characterised by considerable temporal changes in microbenthic biomass and composition (Hamels et al. 1998, Lucas \& Holligan 1999). During this survey, some large epipelic cells, raphid diatoms, were also observed but only during summer in sediments of Stns I and $V$, when grain size was smaller due to low hydrodynamism. The summer silting of these 2 stations seems to be supported by their characteristics: oyster beds for Stn I and ridge and runnel features for Stn V. The other 3 stations do not undergo such significant silting, and assemblages are still dominated by small epipsammic cells.

Nevertheless, large epipelic diatoms in muddy stations are not responsible for the highest biomass values measured in Bourgneuf sediment samples as expected. This implies factors other than granulometry in the structuring of microphytobenthos biomass. Thus, the PAB measured during the survey shows a negative correlation with the muddy fraction of the sediments, in contrast to similar ecosystems (Table 7). In the sampling area studied, results are consistent with previous data obtained by remote sensing (Méléder et al. 2003a,b). SPOT image calibration through NDVI (normalised difference vegetation index) calculation provided information on microphytobenthos coverage: low NDVI values corresponded to low coverage whereas high NDVI values were associated with high coverage. An example of a calibrated image is given in 
Table 7. Biomass distribution (spatial and temporal) in other temperate intertidal mudflats. +/-: positive/negative correlation

\begin{tabular}{|c|c|c|c|c|}
\hline Locality & Chl a range $\left(\mathrm{mg} \mathrm{m}^{-2}\right)$ & Spatial & Temporal & Source \\
\hline $\begin{array}{l}\text { Tagus Estuary } \\
\left(38^{\circ} \mathrm{N}, 9^{\circ} \mathrm{W}\right)\end{array}$ & $11-300(10 \mathrm{~mm})$ & $\begin{array}{l}\text { + with fine sediments } \\
\text { and tidal height }\end{array}$ & No clear seasonal trend & Brotas et al. (1995) \\
\hline $\begin{array}{l}\text { Gironde Estuary } \\
\left(45^{\circ} 20^{\prime} \mathrm{N}, 0^{\circ} 45^{\prime} \mathrm{W}\right)\end{array}$ & $15-140(10 \mathrm{~mm})$ & $\begin{array}{l}\text { + with salinity gradient } \\
\text { and tidal height }\end{array}$ & $\begin{array}{l}\text { Maxima at the end } \\
\text { of spring and summer }\end{array}$ & Santos et al. (1997) \\
\hline \multirow[t]{2}{*}{$\begin{array}{l}\text { Westerschelde Estuary } \\
\left(51^{\circ} \mathrm{N}, 4^{\circ} \mathrm{W}\right)\end{array}$} & 21-939 (10 mm) & - with sandy fraction & $\begin{array}{l}\text { Silty stations: bloom in spring } \\
\text { and decrease in summer }\end{array}$ & Hamels et al. (1998) \\
\hline & $\begin{array}{l}1.1-1.3(2 \mathrm{~mm} ; \text { sand }) \\
57-270(2 \mathrm{~mm} ; \mathrm{mud})\end{array}$ & & $\begin{array}{l}\text { Sandy stations: } \\
\text { no clear seasonal trend }\end{array}$ & Lucas \& Holligan (1999) \\
\hline $\begin{array}{l}\text { Marennes-Oléron Bay } \\
\left(45^{\circ} 50^{\prime} \mathrm{N}, 1^{\circ} 10^{\prime} \mathrm{W}\right)\end{array}$ & $4-465(10 \mathrm{~mm})$ & $\begin{array}{l}\text { No structural factor } \\
\text { dominant }\end{array}$ & Maximum in spring & Guarini et al. (1998) \\
\hline $\begin{array}{l}\text { Bourgneuf Bay } \\
\left(47^{\circ} \mathrm{N}, 2^{\circ} \mathrm{W}\right)\end{array}$ & $\begin{array}{l}12.2-186.9(2 \mathrm{~mm}) \\
26-389(10 \mathrm{~mm})\end{array}$ & + with sandy fraction & No clear seasonal trend & This study \\
\hline
\end{tabular}

Fig. 1b, associated with station localisation. Moreover, during the sampling period, the lower-transect station showed a high water content in sediments (Perkins et al. 2003), whereas the upper-transect station was subject to greater desiccation, de-watering and temperature effects, which can be increased by a long period of emersion (Underwood \& Kromkamp 1999). These factors result in a monomodal distribution of biomass across the intertidal flat, with the peak somewhere between mid-tide level and mean high water neap tide level and not necessarily at the highest bathymetric level as found by Guarini et al. (1998) (Underwood \& Kromkamp 1999). The biomass distribution in the Bourgneuf Bay mudflat is clearly monomodal and centred on Stn III, near to the mid-tide level (Figs. 1b \& 2b).

\section{Sampling scale}

The negative correlation between mud fraction and biomass could also be explained by the low number of samples taken from muddy sediments: 8 samples out of the 52 analysed. Maybe the representativeness of the muddy conditions over the bay was not effective due to the difficulty in reaching the finest sediment area, beyond the isobath $+2 \mathrm{~m}$ where the microphytobenthos biomass maximum occurs (Méléder et al. 2003b). This illustrates the difficulty of extrapolating to macroscale the results of the structure obtained at mesoscale.

On the other hand, the mesoscale sampling programme, chosen to assess microphytobenthos structure in relation to sediment characteristics, enabled observation of the microscale variability. Indeed, there were differences between the 3 PAB values measured for a given station in a given month, illustrated by SD. This PAB heterogeneity at the microscale, stronger for the highest biomass values, illustrates that $\mathrm{PAB}$, mainly due to small epipsammic diatoms, increases by patches without forming a continuous biofilm. This is in accordance with the observations of Saburova et al. (1995) showing aggregations at the microscale of attached and non-attached diatoms on a sandflat. Aggregation is also observed at the macroscale on the MarennesOléron mudflat, where benthic microalgae biomass obeys a 'constant-density model' that describes the alternating spreading/shrinkage phenomenon around the few persistent patches of maximum biomass (Guarini et al. 1998).

\section{Vertical profiles}

PAB represents on average $40 \%$ of the biomass in the first $10 \mathrm{~mm}$. This accumulation of biomass in the photic zone has a physiological significance: microphytobenthic cells were in the layer where irradiance allows photosynthesis. Moreover, these assemblages in the photic zone presented a good physiological status and a low fraction of grazed cells with a reduced amount of breakdown products.

In this study, biomass profiles were more marked in spring/summer 2001, particularly at Stns I and V where grain size decreases. This could be linked to a low hydrodynamism during this period, resulting in weak mixing of sediment. Moreover, large epipelic cells, dominating the summer assemblages of these 2 stations, could migrate in the photic zone to optimise photosynthesis, which the small epipsammic cells, dominating the assemblages of the other stations and the other seasons, cannot do. This results in a more equal distribution with depth of attached diatoms in sandy sediments, mainly due to passive burying linked to high hydrodynamism, as opposed to the accumulation in the first $2 \mathrm{~mm}$ of non-attached diatoms in muddy sediments, linked to active migration. 
Biomass distribution with depth was followed by an increase in phaeo $\mathrm{a} / \mathrm{chl} \mathrm{a}$ and fuco/chl a ratios, also more marked in spring/summer 2001. This confirms the contrast between muddy and sandy sediments observed using a vertical distribution of biomass and assemblage types.

\section{Synthesis}

The results can be synthesised using a conceptual model of the spatio-temporal changes of the microphytobenthos structure in relation to environmental factors at mesoscale (Fig. 6). These meso-spatial and temporal changes of microphytobenthos structure are observed using species diversity, biomarker pigments, phaeo $a / c h l$ a ratio and vertical profiles. We propose that the variations in microphytobenthos structure linked to biotic and abiotic factors operate from a major microalgal assemblage, found in all stations during autumn/winter. This assemblage, responsible for high biomass values, is dominated by epipsammic species colonising mixed sediments and showing a good physiological status. It is poorly influenced by macrophytic debris and vertical profiles are characteristic of mixed sediments (bold box, Fig. 6).

During autumn/winter, high hydrodynamism is responsible, especially at mid-transect stations, for a decrease in sediment mud content due to resuspension of the finest particles and for a significant import of macrophytic debris. This involves a small increase in the phaeo a/chl a ratio as well as sediment mixing and thus less marked vertical profiles. Resuspension could be responsible for a decrease in PAB.

Spring/summer is mainly characterised by low hydrodynamism and high grazing pressure. Hydrodynamism accounts for sediment silting due to fine particle deposition, especially at lower- and uppertransect stations, supporting epipelic species as well as sporadic Euglenophyceae, Chlorophyceae and even Cyanophyceae occurrence. These summer assemblages are potentially responsible for an increase in the PAB (Fig. 6, dotted box, not observed during this survey). However, grazing activity limits the PAB and is responsible for the highest increase in phaeopigments a. Moreover, vertical profiles of biomass and ratios are well

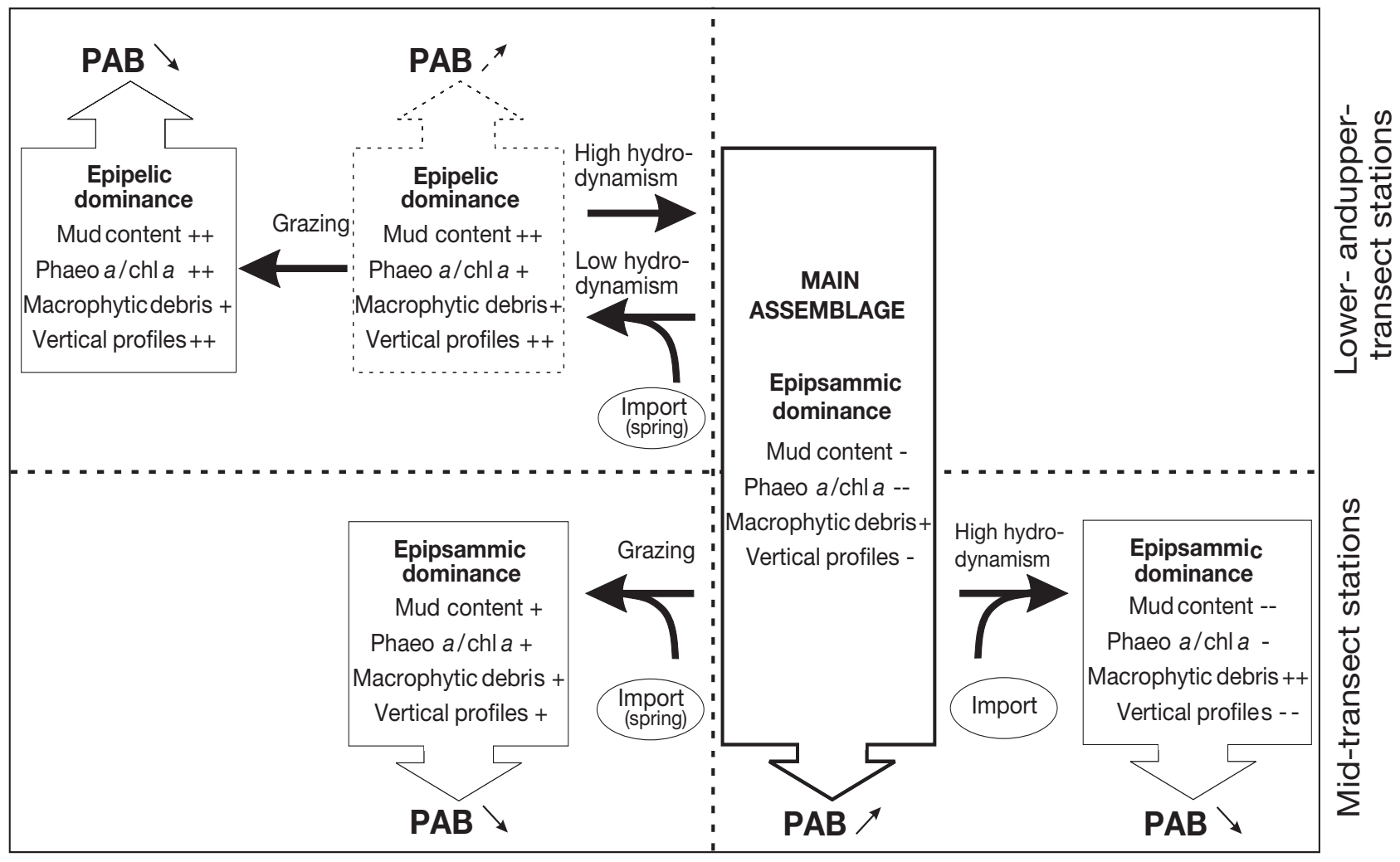

Spring / Summer

Autumn / Winter

Fig. 6. Spatio-temporal changes in microphytobenthos structure synthesis. They vary with space (ordinate) and season (abscissa) from the main assemblage (bold box). Summer assemblage at muddy stations, potentially responsible for an increase in the PAB, is reported (dotted box), although it was not observed in this study. $+/-$, relative scale against the main assemblage: -- very poor, - poor, + high, ++ very high. PAB, photosynthetic active biomass increase $(\nearrow)$ or decrease $(\searrow)$ 
marked due to a reduced mixing of sediments while the accumulation of biomass in the photic zone is also linked to the active migration of epipelic species by phototactism. During the spring months, some macrophytic debris is imported from the water column, but these imports are less than those observed during winter.

At mid-transect stations, the spring/summer effects are not so clear. Assemblages are still dominated by epipsammic species, although mud content increases. Structure is mainly influenced by grazing, responsible for the phaeo $a / c h l ~ a$ increase, concomitant with PAB decrease. The spring macrophytic debris import also participates in the phaeo a/chl a increase, whereas low hydrodynamism is responsible for more marked vertical profiles, although these are less marked when epipelic species dominate the assemblage.

The extrapolation of this synthesis to macroscale needs more information about microphytobenthos structure on the same scale. It requires a greater sampling effort, like the one performed by Guarini et al. (1998) to describe the microphytobenthos spatial structure in Marennes-Oléron Bay (France). However, it has been demonstrated in recent studies that remote sensing could be an alternative to systematic field sampling (Méléder et al. 2003b, J.-Ph. Combe et al. unpubl.), and this technique now seems to be the more promising method to survey and monitor coastal ecosystems at macroscale.

\section{LITERATURE CITED}

Abele-Oeschger D, Theede H (1991) Digestion of algal pigments by the common periwinkle Littorina littorea $\mathrm{L}$. (Gasteropoda). J Exp Mar Biol Ecol 147:177-184

Agreste (2003) Recensement de la conchyliculture en 2002. Ministère de l'Agriculture, de l'Alimentation, de la Pêche et des Affaires Rurales, Paris

Austen I, Andersen TJ, Edelvang K (1999) The influence of benthic diatoms and invertebrates on the erodibility of an intertidal a mudflat, the Danish Wadden Sea. Estuar Coast Shelf Sci 49:99-111

Bachelet G, Castel J, Desprez M, Marchand J (1997) Biocénoses des milieux esturariens. In: Dauvin JC (ed) Les biocénoses marines et littorales françaises des côtes Atlantique, Manche et Mer du Nord, synthèse, menaces et perspectives. Museum National d'Histoire Naturelle, Paris, p 130-140

Baize D (1988) Guide des analyses courantes en pédologie. INRA, Paris

Barillé L, Prou J, Héral M, Razet D (1997) Effects of high natural seston concentrations on the feeding, selection, and absorption of the oyster Crassostrea gigas. J Exp Mar Biol Ecol 212:149-172

Barillé-Boyer AL, Haure J, Baud JP (1997) L'ostréiculture en baie de Bourgneuf. Relation entre la croissance des huîtres Crassostrea gigas et le milieu naturel: synthèse de 1986 à 1995. Report No. DRV/RA/RST/97-16. IFREMER, Bouin

Bianchi TS, Findlay S, Fontvieille D (1991) Experimental degradation of plant materials in Hudson River sediments. I. Heterotrophic transformations of plant pigments. Biochemistry 12:171-187

Blanchard GF, Chrétiennot-Dinet MJ, Dinet A, Robert JM (1988) Méthode simplifiée pour l'extraction du microphytobenthos des sédiments marins par le gel de silice Ludox. CR Acad Sci Paris III 307:569-576

Blott SJ, Pye K (2001) Gradistat: a grain size distribution and statistics package for the analysis of unconsolidated sediments. Earth Surf Process Landf 26:1237-1248

Brotas V, Plante-Cuny MR (1996) Identification et quantification des pigments chlorophylliens et caroténoïdes des sédiments marins: un protocole d'analyse par HPLC. Oceanol Acta 19:623-634

Brotas V, Plante-Cuny MR (1998) Spatial and temporal patterns of microphytobenthic taxa of estuarine tidal flats in the Tagus Estuary (Portugal) using pigment analysis by HPLC. Mar Ecol Prog Ser 171:43-57

Brotas V, Plante-Cuny MR (2003) The use of HPLC pigment analysis to study microphytobenthos communities. Acta Oecol 24:S109-S115

Brotas V, Cabrita T, Portugal A, Serôdio J, Catarino F (1995) Spatio-temporal distribution of microphytobenthic biomass in intertidal flats of Tagus estuary. Hydrobiologia 300/301:93-104

Buffan-Dubau E, de Wit R, Castel J (1996) Feeding selectivity of harpacticoid copepod Canuella perplexa in benthic muddy environments demonstrated by HPLC analyses of chlorin and carotenoid pigments. Mar Ecol Prog Ser 137: 71-82

Cariou-Le Gall V, Blanchard G (1995) Monthly measurements of pigment concentration from an intertidal muddy sediment of Marennes-Oleron, France. Mar Ecol Prog Ser 121: 171-179

Cartaxana P, Jesus B, Brotas V (2003) Phaeophorbide and phaeophytin a-like pigments as useful markers for intertidal microphytobenthos grazing by Hydrobia ulvae. Estuar Coast Shelf Sci 58:293-297

Colijn F, Dijkema KS (1981) Species composition of benthic diatoms and distribution of chlorophyll-a on an intertidal flat in the Dutch Wadden Sea. Mar Ecol Prog Ser 4:9-21

De Jonge VN (1980) Fluctuations in the organic carbon to chlorophyll a ratios for estuarine benthic diatom populations. Mar Ecol Prog Ser 2:345-353

De Jonge VN (1985) The occurrence of 'epipsammic' diatom populations: a result of interaction between physical sorting of sediment and certain properties of diatom species. Estuar Coast Shelf Sci 21:607-622

De Jonge V, Van Beusekom J (1992) Contribution of resuspended microphytobenthos to total phytoplankton in the Ems Estuary and its possible role for grazers. Neth J Sea Res 30:91-105

Ford RB, Honeywill C (2002) Grazing on intertidal microphytobenthos by macrofauna: is phaeophorbide a a useful marker? Mar Ecol Prog Ser 229:33-42

Gruet Y (1972) Faune associée de 'récifs' d'Hermelles Polychète Sabellariidé: Sabellaria alveolata (Linné): cas de récifs morts à Crève-Coeur (La Bernerie, Loire Atlantique). Bull Soc Sci Bretagne 67:69-80

Gruet Y (1977) Répartition de quelques Mollusques Lacunidae (genre Littorina et Melaraphe) et du Trochidae Monodonta lineata (Da Costa) sur l'estran des côtes de Loire-Atlantique et du nords de la Vendée. Bull Soc Sci Nat Ouest France 75:30-34

Guarini JM, Blanchard G, Bacher C, Gros P and 6 others (1998) Dynamics of spatial patterns of microphytobenthic biomass: inferences from a geostatistical analysis of 2 
comprehensive surveys in Marennes-Oléron Bay (France). Mar Ecol Prog Ser 166:131-141

Hamels I, Sabbe K, Muyleart K, Barranguet C, Lucas C, Herman P, Vyverman W (1998) Organisation of microbenthic communities in intertidal estuarine flats, a case study from the Molenplaat (Westerschelde estuary, The Netherlands). Eur J Protistol 34:308-320

Haure J, Baud JP (1995) Approche de la capacité trophique dans un bassin ostréicole (Baie de Bourgneuf). Report No. RIDVR-95-96/RA-BOUIN. IFREMER, Bouin

Haure J, Sauriau PG, Baud JP (1996) Effets du vent sur la remise en suspension particulaire en baie de Bourgneuf: conséquences sur la croissance de Crassostrea gigas. J Rech Océanogr 11:21-30

Héral M (1993) Why carrying models are useful tools for management of bivalve molluscs culture. In: Dame RF (ed) Bivalve filter feeders in estuarine and coastal ecosystem processes, Vol 33. Springer, Berlin, p 455-477

Hustedt F (1927-1966) Die Kieselalgen Deutschlands, Österreichs und der Schweiz. In: Dr L Rabenhorsts Kryptogamen-Flora von Deutschland, Österreich und der Schweiz. Akademische Verlagsgesellschaft, Leipzig

Hustedt F (1930) Bacillariophyta (Diatomaceae). In: Pascher A (ed) Die Süsswasserflora Mitteleuropas. Gustav Fischer, Jena, p 466

Jeffrey SW (1974) Profiles of photosynthetic pigments in the ocean using thin-layer chromatography. Mar Biol 26: $101-110$

Jeffrey SW, Hallegraeff GM (1987) Chlorophyllase distribution in 10 classes of phytoplankton: a problem for chlorophyll analysis. Mar Ecol Prog Ser 35:293-304

Jeffrey SW, Vesk M (1997) Introduction to marine phytoplankton and their pigment signatures. In: Jeffrey SW, Mantoura RFC, Wright SW (eds) Phytoplankton pigments in oceanography. Monographs on oceanographic methodology. UNESCO Publishing, Paris, p 37-84

Jørgensen BB, Des Marais DJ (1986) A simple fiber-optic microprobe for high-resolution light measurements: application in marine sediment. Limnol Oceanogr 31: 1376-1383

Kühl M, Lassen C, Jørgensen BB (1994) Light penetration and light intensity in sandy marine sediments measured with irradiance and scalar irradiance fiber-optic microprobes. Mar Ecol Prog Ser 105:139-148

Lazure P (1992) Etude de l'hydrodynamisme de la baie de Bourgneuf. Report No. DEL/ 92-24. IFREMER, Bouin

Le Bris S, Plante-Cuny MR, Vacelet E (1998) Characterisation of bacterial and algal pigments and breakdown products by HPLC in mixed fresh-water planktonic populations. Arch Hydrobiol 143:409-434

Lohr M, Wilhelm C (1998) Pigment synthesis and xanthophyll cycle in diatoms under high light stress and during low light recovery. In: Garab G (ed) Photosynthesis: mechanisms and effects. Kluwer, Dordrecht, p 2313-2316

Lucas CH, Holligan PM (1999) Nature and ecological implications of algal pigment diversity on the Molenplaat tidal flat (Westerscheldt estuary, SW Netherlands). Mar Ecol Prog Ser 180:51-64

MacIntyre H, Geider R, Miller D (1996) Microphytobenthos: the ecological role of the 'secret garden' of unvegetated, shallow water marine habitats. I. Distribution, abundance and primary production. Estuaries 19:186-201

Mackey MD, Mackey DJ, Higgins HW, Wright SW (1996) CHEMTAX - a program for estimating class abundances from chemical markers: application to HPLC measurements of phytoplankton. Mar Ecol Prog Ser 144: 265-283
Mantoura RFC, Llewellyn CA (1983) The rapid determination of algal chlorophyll and carotenoid pigments and their breakdown products in natural waters by reverse-phase high-performance liquid chromatography. Anal Chim Acta 151:297-314

Méléder V, Barillé L, Launeau P, Carrère V, Rincé Y (2003a) Spectrometric constraint in analysis of benthic diatom biomass using monospecific cultures. Remote Sens Environ 88:386-400

Méléder V, Launeau P, Barillé L, Rincé Y (2003b) Cartographie des peuplements du microphytobenthos par télédétection spatiale visible-infrarouge dans un écosystème conchylicole. CR Acad Sci Paris-Biologie 326:377-389

Oelze J (1985) Analysis of bacteriochlorophylls. Meth Microbiol 18:257-283

Pastoureaud A, Heral M, Prou J, Razet D, Russu P (1996) Particle selection in the oyster Crassostrea gigas (Thunberg) studied by pigment HPLC analysis under natural food conditions. Oceanol Acta 19:79-88

Paterson DM, Hagerthey SE (2001) Microphytobenthos in contrasting coastal ecosystems: biology and dynamics. In: Reise K (ed) Ecological comparisons of sedimentary shores, Vol 151. Springer, Berlin, p 105-125

Peragallo H, Peragallo M (1897-1908) Diatomées marines de France et des districts maritimes voisins. MJ Tempère, Grez-sur-Loing

Perkins RG, Honeywill C, Consalvey M, Austin HA, Tolhurst TJ, Paterson DM (2003) Changes in microphytobenthic chlorophyll a and EPS resulting from sediment compaction due to de-watering: opposing patterns in concentration and content. Cont Shelf Res 23:575-586

Pinckney JL, Carman KR, Lumsden SE, Hymel SN (2003) Microalgal-meiofaunal trophic relationships in muddy intertidal estuarine sediments. Aquat Microb Ecol 31: 99-108

Plante R, Plante-Cuny MR, Reys JP (1986) Photosynthetic pigments of sandy sediments on the north Mediterranean coast: their spatial distribution and its effect on sampling strategies. Mar Ecol Prog Ser 34:133-141

Plante-Cuny MR, Barranguet C, Bonin D, Genz C (1993) Does chlorophyllide a reduce reliability of chlorophyll a measurements in marine coastal sediment? Aquat Sci 55: $19-30$

Porra RJ, Pfündel EE, Engel N (1997) Metabolism and function of photosynthetic pigments. In: Jeffrey SW, Mantoura RFC, Wright SW (eds) Phytoplankton pigments in oceanography Monographs on Oceanographic Methodology. UNESCO Publishing, Paris, p 85-126

Riera P, Richard P (1996) Isotopic determination of food sources of Crassostrea gigas along a trophic gradient in the estuarine bay of Marennes-Oléron. Estuar Coast Shelf Sci 42:347-360

Riethmüller R, Heineke M, Kühl H, Keuker-Rüdiger R (2000) Chlorophyll a concentration as an index of sediment surface stabilisation by microphytobenthos? Cont Shelf Res 20:1351-1372

Rincé Y (1993) Les diatomées marines de la région de BasseLoire: inventaire, distribution spatio-temporelle et devenir expérimental des peuplements naturels d'écosystèmes ostréicoles. PhD thesis, Université de Nantes

Round FE, Crawford RM, Mann DG (1990) The diatoms: biology and morphology of the genera. Cambridge University Press, Cambridge

Saburova MA, Polikarpov IG, Burkovsky IV (1995) Spatial structure of an intertidal sandflat microphytobenthic community as related to different spatial scales. Mar Ecol Prog Ser 129:229-239 
Schlüter L, Møhlenberg F, Havskum H, Larsen S (2000) The use of phytoplankton pigments for identifying and quantifying phytoplankton groups in coastal areas: testing the influence of light and nutrients on pigment/chlorophyll $a$ ratios. Mar Ecol Prog Ser 192:49-63

Underwood GJC, Kromkamp J (1999) Primary production by phytoplankton and microphytobenthos in estuaries. In: Nedwell DB, Raffaelli DG, Fitter A (eds) Advances

Editorial responsibility: Otto Kinne (Editor-in-Chief), Oldendorf/Luhe, Germany in ecological research, Vol 29, Elsevier, p 93-153 Van Der Werff A, Huls H (1957-1974) Diatomeeënflora van Nederland, Otto Koeltz Science Publishers, Koenigstein Wright SW, Jeffrey SW, Mantoura RFC, Llewellyn CA, Bjørnland T, Repeta D, Welschmeyers N (1991) Improved HPLC method for the analysis of chlorophylls and carotenoids from marine phytoplankton. Mar Ecol Prog Ser 77: $183-196$

Submitted: October 18, 2004; Accepted: March 31, 2005 Proofs received from author(s): July 18, 2005 